Online: http://journal.uny.ac.id/index.php/jppfa

\title{
TEACHER'S LEADERSHIP IN LEARNING PROCESSES AT KINDERGARTENS
}

Maria Dominika Niron, Suyata, Siti Partini Suardiman

FIP Universitas Negeri Yogyakarta, Program Pascasarjana Universitas Negeri Yogyakarta inamarni05@gmail.com

\begin{abstract}
The aim of this study was to find out the effective kindergarten teacher's behaviour in influencing, mobilizing, and developing students in teaching learning process. This research was phenomenological qualitative research. The main instruments of this research were the researcher and observation manual. The focus of this research was the way teachers teach in learning process in group A of Indriyasana Kindergarten, Indriarini Kindergarten, and ABA Pokoh Kindergarten. The data validity of this research was tested by using repeated observation, resource triangulation, and technique triangulation. The componential data was analysed by employing inductive technique from Spradley's qualitative model and Miles and Huberman analysis model. The result of the research showed that teacher's effective ways to influence, mobilize, and develop students in teaching learning process are as follows: 1. Reciting yell, clap yell, and asking students to sing. The content of yell, clap yell, and song was appropriate with values which were developed based on vision, mission, and the goal of Kindergarten institution. Yells, clap yell, and song were democratic and they were the form of the value of learning leadership. 2. In some situations, there was a tendency where teacher used more autocratic way to influence, mobilize, and develop students in learning process such as: verbal way in which teacher call students' name and non-verbal way in which teacher put his index finger on his lip as a sign to ask students to be quiet. The other nonverbal ways were: shaking head as a sign of disagreement, raising thumb as a sign of reinforcement, and nodding as sign of agreement. Sometimes, teachers also used laissez-fair methods such as neglecting students/letting students behave as they want.
\end{abstract}

Keywords: leadership, teacher's leadership behaviour, learning process in Kindergarten 


\section{INTRODUCTION}

To be a Kindergarten teacher is not easy. A kindergarten teacher must have sincere and great love for his/her students and energetic, interesting and good personality. In addition, a kindergarten teacher must master education science, psychology of children development, basic concept of study field and the science of getting students learning (Suyanto, 2003, p. 13). The high quality Pendidikan Anak Usia Dini (PAUD) is expected to be able to help parents' role in preparing their children's future (Tientje \& Iskandar. 2004, p.16). Educating children is educating citizen. Children are the main potency for nation's future, the holder of important role, and the responsibility of nation since they are the candidate of successor of family and nation (Dewantara, 1977, p. 2). TK (kindergarten) had been established as formal education institution for preschool (UU RI No. 20 year 2003 about SISDIKNAS, Article 28 verse $1,2,3,4,5)$ and since then people had competed to open kindergarten institution.

Along with people competing to open kindergarten and PAUD, there is thoughtfulness concerning the atmosphere of learning implementation in classroom.

The finding of a research Suwarjo, Maryatun, \& Kusumadewi (2012, p. 70) concerning the implementation of learning process in kindergarten shows that learning process in kindergarten tends to be serious and focuses on academic activities such as reading, writing, and counting. A research Sudarmanto, Pamungkas, \& Putranti (2012, p. 124) concerning teaching method which is used by teacher in teaching-learning process in kindergarten shows that teaching method which is used by teacher (lecturing method) tends to be monotonous and less various and therefore students are less enthusiastic and less interested in learning process. In observation (pre-research) which was conducted in 2013 in some kindergartens, it was found that the learning process was less cheerful. Some students were willing to do task when they were accompanied by the teacher. Sometimes students were afraid of teacher, cried, and asked to go home. Classroom atmosphere was tight and teacher compelled students to read, write, and count (calistung, baca/reading, tulis/writing, and hitung/counting).
Cheerfulness makes students ready to learn in easier way and even can change negative attitude (DePorter, Reardon, \& Nourie, 2006, p. 26). When negative attitude in students' mind changes, students will think positively and always develop positive emotion. In addition, sense of security will stimulate the growth of brain cell especially limbic system in mammal's brain. Actually, cheerfulness and sense of security will trigger positive emotion and this positive emotion will stimulate the growth of brain cell and therefore brain power increases. The growth of brain cell in limbic system is important since limbic system is the main control panel in the system of transference of information from all senses to the part of brain which is used to think (neocortex) and where the wit exists (DePorter \& Hernacki, 2003, p. 28). The wit which is in neocortex will develop when the child is at the age of four years to seven years. This development makes child able to process global learning.

If the atmosphere of learning process in kindergarten is full of cheerfulness, comfort, and sense of security, students will learn with full spirit. If this interesting learning process is not created, students will feel that they are forced to learn and threatened and those who already have learning spirit may lose it (DePorter \& Hernacki, 2003, p. 32).

If students stop learning, they will cover their learning experience unconsciously. Therefore, they will feel nervous and burdened when they hear the word learning. If teacher can change the atmosphere in classroom into the interesting one, he can convey more material and students can understand and remember more material as well (DePorter et al., 2006, p. 64). The interesting and holistic learning experience which is similar to what children get in global learning in their early ages needs to be preserved. This learning experience also needs to be developed in the implementation of learning process of children at their early ages.

The implementation of education in kindergarten should be interactive, inspiring, interesting, challenging, able to motivate students to participate actively and can give enough space for initiative, creativity, and independence according to students' talent, interest, and physical and psychological development (PP No 19 Th 2005 about Standar 
Nasional Pendidikan Article 19 verse 1) and (Petunjuk Teknis Penyelenggaraan Taman Kanak-kanak, 2012: 16). The result of research conducted by Okoroji, Anyanwu, \& Ukpere (2014) shows that interaction between teacher and student is the most important yet most neglected aspect of educational process.

The interaction between teacher and student depends on teacher's ability in leading students. Teacher decides how to mobilize input instrumental optimally and realistically in order to be utilized in teaching-learning process (Nurhadi, 2011, p. 147). The research concerning the labyrinth of teacher leadership which was conducted by Shirley and Miller in 2016 showed that Teacher also know that ability to enhance the quality of their profession is affected by their ability to create robust and international academic, social, and emotional learning experiences of student. The attainment of education goal through teachinglearning process depends on the success of interaction between teacher and student. The interaction between teacher and student depends on teacher and student readiness in joining teaching-learning process (Zamroni, 2007, pp. 1-2). Students' readiness to join teaching-learning process is determined by students' willingness to join teaching-learning process and students' willingness to join teaching-learning process is highly influenced by the feeling of joyfulness and physical and emotional sense of security.

Teacher's role in learning process is as a learning leader who execute the function of learning leadership. Leadership for learning deals with the management of learning quality guarantee which can create a conducive learning environment to develop students completely in order that they can achieve their academic and non-academic performance maximally and be useful for their own life and environment. Learning leadership prioritizes education practices which are appropriate with the base of truth, justice, humanity, and aesthetic; and therefore can create professional human who have good behaviour (Wibowo, 2016, p. 194). As students' leader in learning process, teacher has responsibility to bring students to attain learning goals. In addition, teacher should be able to find out and maximize students' potency and help students to develop their potency until students' ability changes (DePorter et al., 2006, p. 131). The success of learning process which develops students' ability is one of the indicators of the success of teacher's leadership. In learning activity, teacher has important role as leader and the creator of learning system in classroom. Since teacher is the leader who creates learning system, he is responsible for the success of the learning system as well. The result of the research conducted by Petters and Austin as stated by Sallis (2007, pp. 169-170) emphasizes that the factor which determines the quality of education in an institution is teachers' leadership in learning process which is teachers' ability and skill in leading learning process.

In management, there is classic paradigm whose validity is admitted constantly which says that there are four main functions which must be managed optimally in order that management activity can attain its goal. These four functions are planning, organizing, leading, and controlling. Among these functions, leading is the main function since leadership function is hidden in all management functions. Leadership is a characteristic which sticks on leader's self. There must be individual who leads the planning, organizing, and controlling (Moeljono, 2004, pp. 26-27). Teacher's leadership in learning process is a part of class management activity. Teacher's leadership in learning process covers mobilizing, influencing, motivating, asking, directing, giving advice, guiding, ordering, and forbidding. These activities are conducted in order to make students have willingness to learn, to listen what teacher says, and to do what teacher asks. The form of leadership will be visible in teacher's performance and behaviour when he leads and therefore this form of leadership is often called teacher's leadership behaviour. Teacher's leadership behaviour in leading the execution of learning process is teacher's personal ability which is expressed teacher's belief and behaviour in giving vision, values, and culture to his students of the class that he leads (Zamroni, 2007, p. 116). If teacher's vision about class culture is that students have passion and habitus which lead to leadership values, education will produce excellent human in the future (Suharyo, 2009).

In reality, there are still many teachers who are not capable to lead students in learning process. There are some skills that 
have to be mastered by teacher who will lead the learning process in class. These skills are skill to influence students in learning, skill to mobilize students to learn, skill to develop students' ability through learning process, and skill to empower students in learning process (Departemen Pendidikan Nasional, 2011, p. 12). The conception of empowering means making powerful. If this conception is implemented in learning process, the meaning will be making students participating in succeeding the learning process. The skill to empower students in learning process will be concretely visible through teacher's behaviour in giving chance and putting trust in students to practice and exercise. Therefore, the conception of empowering students has been expressed implicitly in the meaning of skill to influence, skill to mobilize, and skill to develop students. With these three leadership skills, students are asked and directed to participate in learning process, have willingness to listen what their teacher says, and have willingness to do what their teachers asks actively, creatively, and independently until they are able to express the result of their learning process. The implementation of these skills will be visible through teacher's behaviour in guiding, helping, and assigning students.

Given the fact that it is important for teacher to master leadership skill, the researcher wanted to research Teacher's Leadership in Learning Processes at Kindergartens by modifying the conception from LPPKS Indonesia. The phenomenon of teacher's leadership which was researched in this research is the way teacher influence, mobilize, and develop students in order that students will have willingness to listen what their teacher says, to do what their teacher asks, to be asked, and to be directed to participate in learning process actively, creatively, and independently until students are able to express the result of their learning process.

The phenomenon of teacher's leadership in learning process in kindergarten will be directed in the setting where kindergarten teachers makes students learning in learning activity in group A. The learning setting in group A was selected since education in group A is more about transition period between informal learning situation at home and structured learning situation at school and it is important to research teacher's leadership in learning process in group A. This research was conducted in three out of 12 kindergartens in Wedomartani village, Ngemplak subdistrict, Sleman regency. These three kindergartens are Indriyasana Kindergarten (one group), PKK Indriarini Kindergarten, and ABA Kindergarten (two groups). The problems which became the background of this research are as follows: Learning process in kindergarten group A tends to be serious and focuses on academic activities such as reading, writing, and counting. The feedback interaction between student and teacher and interaction among students are less visible. The interaction is only that students pay attention to what their teacher explains. Communication in learning together is almost rarely visible. Students always tend to do their task by themselves. They seldom work together. The teaching method which is used by teacher tends to be monotonous (lecturing method). Learning media which is used by teacher in learning process in Kindergarten is less various. There are many students who are less enthusiastic and less interested in joining the learning process. Learning atmosphere often looks tight where many students are inside classroom but they do not have willingness to do learning activity. There are some students who do the task only when they are accompanied by their teacher. There are some students who are afraid of their teacher. These students do not want to enter the classroom when they arrive at school. They cry, ask to go home, and say, "I'm afraid of my teacher." There are some teachers who often "force" students to learn reading, writing, and counting (calistung). There are still teachers who are not able to manage students in small groups. These teachers also need to motivate more.

The focus of this research would see the phenomenon of teacher's leadership behaviour in group A of Kindergarten which covered: The effective teacher's way in influencing students in order that they want to learn actively, creatively, and independently until they are able to express the result of their learning process. The effective teacher's way in mobilizing students in order that they want to learn actively, creatively, and independently until they are able to express the result of their learning process. The effective teacher's way in developing students' skill in order that they 
want to learn actively, creatively, and independently until they are able to express the result of their learning process.

This research was conducted to find out the description of teacher's leadership behaviour in group A of Kindergarten concerning: The effective teacher's way in influencing students in order that they want to learn actively, creatively, and independently until they are able to express the result of their learning process. The effective teacher's way in mobilizing students in order that they want to learn actively, creatively, and independently until they are able to express the result of their learning process. The effective teacher's way in developing students' skill in order that they want to learn actively, creatively, and independently until they are able to express the result of their learning process.

\section{METHOD}

This research used phenomenological qualitative approach. This research was being conducted since the permission to conduct this research was released until the researcher got the answers of the research problem concerning the most effective leadership behaviour in learning process.

This research was conducted in three Kindergartens. There were five groups which were involved in this research. These kindergartens are Indriyasana Kindergarten (one group), PKK Indriarini Kindergarten (two groups), and ABA Kindergarten (two groups). The subjects of this research were homeroom teachers of group A of kindergarten in Indriyasana Kindergarten, PKK Indriarini Kindergarten, and ABA Kindergarten.

The field that would be analysed was teacher's leadership behaviour in learning activity in Kindergarten. The instrument which was used was the indicator manual of teacher's leadership behaviour in learning activity in Kindergarten. The main techniques of data collecting in this research were observation, interview, and documentation. Observation method was intended to find out the teacher's leadership behaviour in learning activity. This behaviour covered the way teacher influence, mobilize, push, motivate, and develop students in learning activity. All information that was found was then noted as observation result. The result of observation was used by the researcher as a proof for analysis material. The unstructured interview was conducted pronto without manual in order to clarify information which was attained from observation or document. Documentation which was researched was all documents concerning students' learning result. The componential data was analysed by employing inductive technique from Spradley's qualitative model and Miles and Huberman analysis model.

\section{THE RESULT OF THE RESEARCH AND DISCUSSION}

\section{The Result of the Research}

The result of the research showed that the effective ways to influence, mobilize, and develop students in learning process in order that they want to listen what their teacher says and to do what teacher asks actively, creatively, and independently until they are able to express the result of their learning process were as follows: 1. Reciting yell, clap yell, and asking students to sing. The content of yell, clap yell, and song was appropriate with values which were developed based on vision, mission, and the goal of Kindergarten institution. Yells, clap yell, and song were democratic and they were the form of the value of learning leadership. 2. In some situations, there was a tendency where teacher used more autocratic way to influence, mobilize, and develop students in learning process such as: verbal way in which teacher call students' name and non-verbal way in which teacher put his index finger on his lip as a sign to ask students to be quiet. The other non-verbal ways were: shaking head as a sign of disagreement, raising thumb as a sign of reinforcement, and nodding as sign of agreement. Sometimes, teachers also used laissez-fair methods such as neglecting students/ letting students behave as they want.

\section{Discussion}

Teacher's leadership behaviour in learning process which is called instructional leadership (Hoy \& Miskel, 2014, p. 654) is a part of strategy in class management or learning management which emphasises the betterment of learning process. The real conception of learning leadership is a way or strategy to 
make learning process more interesting to all students by more counting on the power of relationship or interaction between teacher as leader and students as people who are led (Donaldson, 2007, pp. 26-29).

The result of this research showed that the effective ways which were used by teacher to influence, mobilize, and develop students in learning process are as follows: Firstly, reciting yells, clap yell, and asking students to sing. The content of yells, clap yell, and song was appropriate with values which were developed based on vision, mission, and the goal of Kindergarten institution. Yells, clap $y e l l$, and song were democratic and they were the form of the value of learning leadership. Secondly, in some situations, there was a tendency where teacher used more autocratic way to influence, mobilize, and develop students in learning process such as: verbal way in which teacher call students' name and non-verbal way in which teacher put his index finger on his lip as a sign to ask students to be quiet. The other non-verbal ways were: shaking head as a sign of disagreement, raising thumb as a sign of reinforcement, and nodding as sign of agreement. Sometimes, teachers also used neglectful methods such as neglecting students/letting students behave as they want.

Observed from leadership perspective, reciting yells or clap yell or singing a song was a form of the value of learning leadership. This form is democratic and participating. This democratic and participating way involved students actively in learning process. Therefore, when teacher gave order, students had willingness to listen and do what their teacher said. By reciting yells or clap yell or singing a song, teacher consciously gave a chance to students to develop and be responsible. Students were trained to be responsible by doing what they said in yells. Thus, learning atmosphere would be interesting since students were happy. The learning atmosphere which is interesting and full of happiness is needed in learning process in Kindergarten since this atmosphere is needed by the growth of children's brain cell. At the age of 4, the structure of neural-motor censor and emotional cognitive develop up to $80 \%$ and afterwards another wits will develop. However, if children feel threatened, this wits will stop developing
(DePorter \& Hernacki, 2003, p. 32). The example of the yell which was used was "Yel Sahabat Yesus" (Jesus' Friend Yell)

\author{
Teacher: "Sahabat Yesus? (Jesus' \\ friend?)"
Students: "Yes!"
Teacher: "Sahabat setan? (Satan's friend?)" \\ Students: "No!" \\ Teacher: "Anak hebat? (Great \\ children?)" \\ Students: "Yes!" \\ Teacher: "Kalau anak hebat, berarti? (If \\ you are great children, then?)" \\ Students: "Sekarang duduk tenang dan \\ siap belajar. (Now sit quietly and ready \\ to learn)"
}

From student perspective, this way was appropriate with children at the age of kindergarten students' age (4-6 years old). Children who had been able to control their emotion will be sensitive to their peer's feeling as well (Stoica \& Roco, 2013, p. 78). By reciting yells or clap yell or singing a song, students were trained to control their personal feeling.

From education perspective, this way was educative. Dewantara (1977, p. 17) says that education is an effort to realize the growth of someone's personality. The essence of Kindergarten education here is all teacher's attempt which is intended to help students to attain maturity according to their age. The indicator of maturity itself is that students are able to decide what they have to do, take responsible of what they do, and take the risk of their decision. Through reciting yells or clap yell or singing a song, actually the aspect of students' psychology is developed. In this learning process, students are trained to make decision and take the risk of their decision. The example of this learning process is that students are asked to sit quietly and listen to what their teacher says. If the aspect of someone's psychology is developed well, it will bring ability to himself since the element of psychology in someone covers creation, taste, and intention (Dewantara, 1977, p. 23). Yells or clap yells or singing song seems to be 
effective enough to create conducive learning atmosphere which contains the value to create children character. In order to produce democratic Indonesian people who have good work ethos, discipline, good moral, and responsibility, it needs to design and conduct a national education system which enables the learning process which its meaning is a process of cultivation of various skills, values, and attitude of democratic and responsible modern Indonesian people (Soedijarto, 2008, p. 2127). Reciting yells and clap yell and singing a song is a process of cultivation of various skills, values, and attitude which will be developed according to vision, mission, and goals of Kindergarten. In this process, students are playing and learning at the same time. Playing is a volunteer activity which focuses on process and gives reward intrinsically. In addition, Solehudin (Masitoh \& et al., 2009, p. 11) says that this activity is fun and flexible. Citing the opinion of Dockett and Fleer (Masitoh \& et al., 2009) also say that playing for children has some characteristics such as meaningful, active, fun, and volunteer. With yells, clap yell, and singing a song, teacher already ask students to play while students are actively using their psychological abilities such as imagining and thinking. There are behaviour value and children's character which are developed in yells and clap yell. Yells and clap yell also contain cultural values, religion values, and nationality values. With yells or clap yell or singing a song which contains positive life values which are developed based on vision, mission, and goals of each Kindergarten institution, students' psychological aspect is expected to develop. Their psychological aspect is expected to develop since it is directed to positive values. Tilaar \& Nugroho (2008, p. 44) say that education process is a process to give ability to individual in order that he/she can give meaning to himself/herself and the environment. In this opinion, the education process to develop human's ability will be great if there are relationship between human and environment, the communication of all parties, and influence in various activities. Through reciting yells or clap yell or singing a song, actually there is relationship and communication between student and teacher and among friends in the class.

In some situations, there was a tendency where teacher used some ways to influ- ence, mobilize, and develop students. These ways are: verbal way in which teacher called students' name and non-verbal way in which teacher put his index finger on his lip as a sign to ask students to be quiet. The other nonverbal ways were: shaking head as a sign of disagreement, raising thumb as a sign of reinforcement, and nodding as sign of agreement. In leadership perspective, this way is autocratic and some people also name it telling. In this autocratic leadership behaviour or telling teacher often gives instruction to students to sit quietly and do something. Then, teacher supervised students tightly. Teacher called the name of students who did not sit quietly or put his index finger on his lip as a sign to ask student to be quiet. Sometimes teacher also shook his head as a sign of disagreement to children who ran around the class. In addition, teacher raised his thumb as a sign of reinforcement and nodded as a sign of agreement to students who sat quietly and did their job. Students had to do those all tasks according to the guide from their teacher. This telling or autocratic way is actually good since students will do their job quietly and therefore there is certainty of the time for students to finish their job. However, this way has weakness since students are not trained to do task based on their idea. This case can make students dependent on their teacher.

Sometimes teacher also used a neglectful method where teacher let students behave as they want. In leadership perspective, the method where teacher let students behave as they want is called laissez-fair. Some people also name it delegating. In leadership perspective, teacher's behaviour where he tends to trust students and heads for students' freedom has advantage and disadvantage as well. This is because students can do anything they consider appropriate for themselves and teacher can be more relaxed. However, in perspective of Kindergarten students, this way has weakness. The weakness is that students will not finish their work when they need a teacher but they cannot find an appropriate teacher. If this case continues, students will lose their hope since they feel that they cannot finish their job. The high spirit of children will vanish if they lose their hope and feel that the learning process is not interesting (DePorter \& Hernacki, 2003, pp. 22-24). Erikson (Suyanto, 2003 , p. 132) says that the early years of 
human's life are crucial years since children can still change their opinion on themselves. To get kindergarten students learning is not easy. Early childhood learning uses the essence of playing which covers joyfulness, democracy, activeness, volunteer, and freedom. Therefore, to get children learning, the environment needs to be arranged to be conducive (Suyanto, 2003, pp. 8-9).

The next analysis was about the condition of each Kindergarten. In general, the ways that were used by teachers to influence, mobilize, and develop students in order that they participate actively in learning activity were various. However, the most effective ways where leadership value was implemented were yells or clap yell method and singing a song. Through yells and song, teacher motivated students as a leadership strategy in learning process. In addition, there was leadership value which was developed. This leadership value was about realizing vision, mission, and special mission of school and foundation. Thus, yells, clap yells and song had become effective strategy of learning leadership and strategy of the development of school's values and character. From the perspective of children at the age of Kindergarten students' age, leadership approach with yells, clap yell, and song needs to be developed. Montessori (Dewantara, 1977, p. 63) says that when deal with education for the children at the age of Kindergarten students' age, it needs to consider the aspect of children's development on each of their psychology development stage. This is because children have spiritual need which will develop the outside condition is good and can push children to do something. Therefore, it needs to develop an approach which develops life values such as introduction to culture, religion, and social values in the society where children live.

Among three kindergartens, the use of yells, clap yell, and song as a form of the value of learning leadership and the strategy of value and school character development was implemented mostly in ABA Pokoh Kindergarten. The second place was PKK Indriarini Kindergarten and the third place was Indriyasana Kindergarten.

ABA Pokoh Kindergarten: Through learning activity which was programmed in curriculum and PAKEM approach, ABA
Pokoh Kindergarten tried to realize the vision and mission of the school and Aisyiyah foundation. The vision and mission was to create human resource who was quality (human resource who is able to face science and technology and can adapt to the recent situation and condition) skilled, and pious. Aisyiyah institution and school aimed to create creative and innovative human resource. In addition, the graduates of Aisyiyah Kindergarten are expected to be deft and have akhlaqul karimah (good behaviour). Aisyiyah Kindergarten also aimed to teach understanding and implementation of Islam continuously. Lastly, Aisyiyah Kindergarten's goal is to realize Islamic life in daily life according to the Qur'an and Hadith. To achieve these goals, ABA Pokoh Kindergarten set main agenda including learning about Sholat (Prayer) and memorizing short Surah, Hadith, and daily prayers. All these materials were given in the simple way that included song, yells, and clap yell. Therefore, it is easier for students to understand. ABA Pokoh Kindergarten mostly used clap yell.

The development of yells, clap yell, and song orientated towards vision, mission, and goal of Kindergarten very much. This development even orientated towards vision, mission, and goal of foundation. Teacher had developed tepuk diam (silent clap). When the teacher practiced this clap, the class suddenly was silent. Through this clap, students are expected to have the character of quality human resource. The character which was taught through this clap was being able to adapt to situation. The other clap was Tepuk Rukun Islam (5 Pillars of Islam) which included 1. Shahadah, 2. Sholat, 3. Puasa (fasting), 4. Zakat, and 5. Naik Haji Ke Mekah (Hajj). Through this clap, teacher taught the understanding and implementation of Islam and realized Islamic life according to the Qur'an and Hadith. Teacher also taught Tepuk Rukun Iman (Pillars of Iman/Faith) which included: 1 Percaya kepada Allah, (believing in Allah) 2 Percaya malaikat Allah (believing in Angels) 3 Percaya kitab Allah, (believing in holy books) 4 Percaya rasul Allah, (believing in Prophet) 5 Percaya hari akhir, (believing in Judgement Day) 6 Percaya qada' dan qadar (believing in fate). Through this clap, teacher taught the understanding and implementation of Islam and realized Islamic life according to the Qur'an and Hadith. The third, teacher 
taught Tepuk Islam (Islam Clap). The verse of Tepuk Islam is as follows:

Tuhanku (plok plok plok) Allah, (My God)

Nabiku (plok plok plok) Muhammad, (My Prophet)

Kitabku (plok plok plok) Al-qur'an, (My Holy Book)

Agamaku (plok plok plok) Islam, (My religion)

Temanku (plok plok plok) orang muslim, (My friend)

Musuhku (plok plok plok) setan. (My enemy)

Through this clap, teacher taught the understanding and implementation of Islam and realized Islamic life according to the Qur'an and Hadith. There was also Tepuk Malaikat (Angels Clap. The verse of Tepuk Malaikat is as follows:

Jibril (plok plok plok),

Mikail (plok plok plok),

Izrail (plok plok plok),

Israfil (plok plok plok),

Munkar (plok plok plok),

Nakir (plok plok plok),

Rakib (plok plok plok),

Atid (plok plok plok),

Ridwan (plok plok plok).

Through this clap, teacher taught the understanding and implementation of Islam and realized Islamic life according to the Qur'an and Hadith. There was also Tepuk Sekolahku (My School Clap). The verse of Tepuk Sekolahku is as follows:

Sekolahku (plok plok plok) 'Aisyiyah Pokoh,

Di dusun (plok plok plok) Rejosari,

Di desa (plok plok plok) Wedomartani,

Kecamatan (plok plok plok) ngemplak,

Kabupaten (plok plok plok) Sleman, horeee.
If the verse above are translated into English, the translation is as follows:

My school (students clap) 'Aisysiyah Pokoh

At dusun (students clap) Rejosari,

At village (students clap) Wedomartani,

Subdistrict (students clap) Ngemplak,

Regency (students clap) Sleman, hurray!

Through this clap, teacher taught students to love their school as a place to study. In addition, teacher also employed Tepuk Masjid (Mosque Clap) in teachinglearning process. The verse of Tepuk Masjid is as follows:

Tepuk masjid...

Mataku melihat Rumah Allah...

Telingaku Mendengar suara adzan...

Tanganku ku angkat dan berdoa...

Kepada Allah yang Maha Rahman.

If the verse above is translated into English, the translation is as follows:

My eyes see Allah's House...

My ears hear adzan...

I raise my hand and pray...

To Allah The Merciful.

Through this clap, teacher taught the understanding and implementation of Islam and realized Islamic life according to the Qur'an and Hadith.

Teacher also introduced world globalization through yell named Good Morning Yells. This verse of this yell is as follows:

Teacher: "Good morning, how are you?"

All students: "Just fine. Good morning to you, good morning to me."

Teacher also asked students to sing a song called Naik Haji (Hajj). This song was modification of a song named Saya Mau Tamasya. The verses of Naik Haji are as follows:

Verse 1: 
Saya mau ke Mekah berkliling killing ka'bah....

Sambil baca Talbiyah dan Wuquf di Arofah....

Sambil melempar Jumrah...

Wula wustha Aqobah...

Sa'I Sa'I dari Shofa ke Marwah...

Verse 2:

Allah Maha Penyayang Sayangnya tak terbilang...

Allah Maha Pengasih Tak pernah Pilih Kasih...

Allah Yang Maha Tahu Tanpa diberi tahu...

Allah.... Allah... La ILLahaiLLaLLah.

Through this song, teacher taught the understanding and implementation of Islam and realized Islamic life according to the Qur'an and Hadith. Teacher also asked students to sing a song called Membuang Sampah (Throwing Garbage Away). The verse of this song is as follows:

ambil sampah...

taroh sampah di tempatnya...

sampah jangan dibuang

sembarangan...

ambil sampah, jadikan berkah,

lestarikan alam ciptaan Allah.

Through this song, teacher taught students to keep environment clean and be responsible in working.

\section{PKK Indriarini Kindergarten}

Through learning activity which was programmed in curriculum, PKK Indriarini Kindergarten tried to realize the vision and mission of school and foundation of Wedomartani village. The mission itself is to create smart, creative, and independent children who have good behaviour and wide knowledge and love their nation. To accomplish this mission, PKK Indriarini Kindergarten conducted learning process according to the need of students and used principle "learning while playing." The learning process in PKK Indriarini Kindergarten was also intended to grow the spirit of competition based on good behaviour and loving the environment. In addition, this learning process was also intended to teach values of character to students through habituation and to give examples of good behaviour in daily life. The yells, clap yell, and song which were developed by teacher to realize the value of learning leadership are as follows:

\section{Yel Duduk Manis (Sitting Quietly Yell)}

This yell was yelled and acted with full spirit. The verse of this yell is as follows:

tangan ke atas seperti pohon...

tangan ke samping seperti burung terbang...

tangan ke depan itulah anak pintar...

tangan dilipat duduk yang manis....

dan...siap...

(can be continued with some words such as "berdoa" (praying) or "belajar" (learning) according to the situation and condition).

Through this yell, teacher taught character values in habituation of good attitude (sitting quietly) in learning activity

\section{Yel Maju}

Teacher: go..go..go..

All students: go..go..go...

\section{Yel TK Indriarini the Best}

Al ...

Yes! TK Indriarini is the best.

A2 ...

Yes! TK Indriarini is the best.

Through Yel Maju and Yel TK Indriani The Best, teacher realized special vision and mission of school and foundation. The special vision and mission was to grow the spirit of competition based on good behaviour.

Teacher also used clap yell and the clap which often used was Tepuk The Best (The Best Clapp). The verse of this clap is as follows:

I' $m$ the best (Students raise their thumbs towards their chest), 
you are the best (Student straighten their hands and point their thumbs to their friend in front of them),

we are the best $2 x$ (Students stretch their hands towards their friends at their left side and right side),

yes, yes (Students clench their hands and raise them).

Through this yell, teacher showed an example of good behaviour in daily life and hoped that this behaviour would become students' habit.

Teacher also used the combination of song and movement. When this combination was employed in teaching learning process, teacher asked students to sing and move according to the content of the song. One example of the combination of song and movement was song called "Tar Diputar." The lyrics of this song are as follows:

\section{Tar diputar- putar, tangan diputar - putar... \\ lung digulung - gulung...tangan digulung-gulung... \\ ular melingkar di pagar bundar... \\ kanan (Students see their right side)... \\ kiri (Students see their left side)... \\ atas (Students see upward)... \\ bawah (Students see downward)... \\ siap belajar.}

The other song which was employed was Pitik Walik. When this song was employed in teaching-learning process, teacher asked students to sing and act based on this song. The lyrics of this song are as follows:

Pitik walik jambul...

Sego golong mambu enthong...

Monggo sami wangsul...

weteng kulo sampun kothong...

Enak e, enak Sego liwet jangan terong...

Teronge bunder-bunder...

Sopo sregep mesti pinter...

Teronge ijio-ijo...

\section{Sopo keset mesti bodoh}

Through this song, teacher taught good behaviour and character values to students. It was expected that good behaviour taught through this song would become students' daily habit. Students were also taught to love the environment.

\section{Indriyasana Kindergarten}

Through learning activity which was programmed in curriculum, Indriyasana Kindergarten tried to realize the vision and mission of Dharma Ibu school and foundation. Dharma Ibu school and foundation aimed to create graduates who are smart, mentally and physically healthy, and pious. These graduates are also expected to have good character and care about environment. The curricular learning activity in this school are intended to realize the mission of this institution. The mission of Dharma Ibu foundation itself is to provide students with sufficient basic skill which was adjusted to match children's development. This basic skill is adjusted to match children's development in order to: First, to train children' wits based on their age. Second, to care about children's health carefully. Third, to develop positive children's behaviour. Fourth, to train children to pray and worship according to the characteristic of school s Catholic education institution. Fifth, to educate children to care about the living environment.

There were some yells which were developed by teacher to realize the value of learning leadership. The first yell was Yel Semangat Yesus (Yell of Jesus' Spirit). The verse of this yell is as follows:

di mana semangatmu?

Ini semangatku...

di mana Yesusmu?

di dalam hatiku...

Through this yell, teacher taught belief to students. Teacher taught that as Jesus' followers, students must have spirit in learning or working.

The second yell was called Yell Sahabat Yesus (Yell of Jesus' Friend). The verse of this yell is as follows: 
Teacher: "Sahabat Yesus? (Jesus' friend?)"

Students: "Yes!"

Teacher: "Sahabat setan? (Satan's friend?)"

Students: "No!"

Teacher: "Anak hebat? (Great children?)"

Students: "Yes!"

Teacher: "Kalau anak hebat, berarti? (If you are great children, then?)"

Students: "Sekarang duduk tenang dan siap belajar. (Now sit quietly and ready to learn)"

Through this yell, teacher taught belief to students. Teacher taught that as Jesus' followers, students should be ready to do task (siap belajar/ready to learn as student).

The third yell was Yell Duduk Manis (Yell of Sitting Quietly). This yell was yelled and acted with full spirit. The verse of this yell is as follows:

tangan ke atas seperti pohon...

tangan ke samping seperti burung terbang...

tangan ke depan itulah anak pintar...

tangan dilipat duduk yang manis....

dan...siap...

(can be continued with some words such as "berdoa" (praying) or "belajar" (learning) according to the situation and condition).

Through this yell, teachers taught a good student' character to students. The good character which was taught was to learn seriously and behave well (duduk yang manis/ sitting quietly).

Teacher also developed some clap yells to realize the value of learning leadership. The first yell was Tepuk Maria. The verse of this clap yell is as follows:

Tepuk Maria...

(plok plok plok), Maria...

(plok plok plok), Maria...

(plok plok plok), Maria luar biasa.
Through this yell, teacher taught the belief of Maria to students who were Jesus' followers.

The second clap yell was Tepuk Jesus/Jesus Clap. The verse of this clap yell is as follows:

$$
\begin{aligned}
& \text { Yesus... (plok plok plok), } \\
& \text { Yesus... (plok plok plok), } \\
& \text { Y... E... S...U... S... } \\
& \text { Yesus...Yesus...... }
\end{aligned}
$$

Through this yell, teacher taught belief attitude of Jesus' followers.

The songs which were employed in learning process tended to be common. The dialogue between teacher and students in learning process which employ song is as follows:

Mrs Ri: "melanjutkan... hari ini kita akan belajar tentang taman bunga yang ada di halaman rumah dan di halaman sekolah kita. ... Siapa yang masih ingat lagu lihat kebunku?"

(Continuing ..., today we will learn about flower park in our house' yard and school' yard. Who still remembers the song Lihat Kebunku?

Students: (Raise their hands with full of spirit).

Mrs Is: "Ibu Is kalau masih ingat lagu lihat kebunku, ....ayo sekarang..., mari kita bernyanyi bersama sambil meragakan ya..."

(If you still remember the song Lihat Kebunku, now let's sing together and act it, okay?)

Mrs Is: (Started to sing and move according to the content of the song).

Students: (All students imitated Mrs Is spontaneously)

"Lihat kebunku (Students open their palm and straighten their hands to the left side and right side)

penuh dengan bunga.... ada yang putih (Students straighten their right hand forward)

dan ada yang merah...(Students straighten their left hand forward) 
setiap hari kusiram semua (Students open their palm and straighten their hands to the left side and right side)

mawar... (Students open their right palm and straighten their right hand forward)

melati. (Students open their left palm and straighten their left hand forward)

semuanya (Students open their palm and straighten their hands to the left side and right side)

indah...(Students clap their hands).

Through this song, teachers taught students to be always cheerful. Students were also reminded to respect and take care of living environment. For belief development, students are taught to be grateful to God by teaching them to care about living environment. In addition, teacher often asked students to sing a song called Pelangi - pelangi. The lyrics of this song are as follows:

$$
\begin{aligned}
& \text { Pelangi-pelangi... } \\
& \text { alangkah indahmu... } \\
& \text { merah, kuning, hijau... } \\
& \text { di langit yang biru... } \\
& \text { pelukismu agung... } \\
& \text { siapagerangan... } \\
& \text { pelangi-pelangi... } \\
& \text { ciptaan Tuhan... }
\end{aligned}
$$

Through this song, students are taught to always know God and to be grateful to God The Almighty Creator.

\section{CONCLUSIONS}

The result of this research shows that the effective teacher's ways in influencing, mobilizing, and developing students in learning process are:1. Reciting yell, clap yell, and asking students to sing. The content of yell, clap yell, and song was appropriate with values which were developed based on vision, mission, and the goal of Kindergarten institution. Yells, clap yell, and song were democratic and they were the form of the value of learning leadership. 2. In some situations, there was a tendency where teacher used more autocratic way to influence, mobilize, and develop students in learning process such as: verbal way in which teacher call students' name and non-verbal way in which teacher put his index finger on his lip as a sign to ask students to be quiet. The other non-verbal ways were: shaking head as a sign of disagreement, raising thumb as a sign of reinforcement, and nodding as sign of agreement. Sometimes, teachers also used laissez-fair methods such as neglecting students/letting students behave as they want.

Based on the findings of this research, the suggestions from the researcher are as follows: For teacher: Teacher needs to arrange many kinds of yell, clap yell, and song which are persuasive. It means that yells, clap yells, and song are expected to be able to ask students to help their friend. For the Principal: The Principal should push teachers to develop more yells, clap yells, and songs which are persuasive and able to help students to learn actively, creatively, and independently and be able to express their learning result. For Kindergarten Supervisor: When giving professional supervision to teachers, Kindergarten Supervisor needs to make a formula concerning yell, clap yell, and song which are persuasive and able to help students to learn actively, creatively, and independently and be able to express their learning result. For Education Department party: In guiding Kindergarten teachers through teachers conference activity, it needs to develop ability to make a formula concerning yell, clap yell, and song which orientate towards vision, mission, and goals of Kindergarten foundation.

\section{REFERENCES}

Departemen Pendidikan Nasional. (2011). Pengantar dan tata laksana penulisan makalah kepemimpinan. Surakarta: Kementerian Pendidikan dan Kebudayaan, Lembaga Pengembangan dan Pemberdayaan Kepala Sekolah (LPPKS).

DePorter, B., \& Hernacki, M. (2003). Quantum learning: membiasakan belajar nyaman dan menyenangkan.(Terjemahan Alwiyah Abdurahman). Bandung: Kaifa.

DePorter, B., Reardon, M., \& Nourie, S. S. 
(2006). Quantum teaching: mempraktikkan quantum learning di ruang-ruang kelas penerjemah Ary Nilandari. (F. Syahrani, Ed.). Bandung: Kaifa.

Dewantara, K. H. (1977). Kumpulan karya Ki Hadjar Dewantara bagian pertama: Pendidikan. Yogyakarta: Majelis Luhur Persatuan Taman Siswa.

Donaldson, G. A. (2007). What do teachers bring to leadership? Educational Leadership, 65(1), 26-29. Retrieved from

http://www.ascd.org/publications/educati onalleadership/sept07/vol65/num01/WhatDo-Teachers-Bring-to-Leadership $\notin$.aspx

Hoy, W. K., \& Miskel, C. G. (2014). Administrasi pendidikan teori, riset dan praktik. Yogyakarta: Pustaka Pelajar.

Masitoh, \& et al. (2009). Materi pokok strategi pembelajaran TK (12th ed.). Jakarta: Universitas Terbuka.

Moeljono, D. (2004). Beyond leadership; 12 konsep kepemimpinan. Jakarta: Gramedia.

Nurhadi, M. A. (2011). Dilema kebijakan pendanaan pendidikan. Yogyakarta: Nurhadi Center.

Okoroji, L. I., Anyanwu, O. J., \& Ukpere, W. I. (2014). Impact of leadership styles on teaching and learning process in Imo state. Mediterranean Journal of Social Sciences, 5(4), 180-193. https://doi.org/10.5901/mjss.2014.v5n4p 180

Sallis, E. (2007). Total quality in education. Yogyakarta: IRCiSoD.

Stoica, A. M., \& Roco, M. (2013). The role of the emotional intelligence in kindergarden children's development.
Procedia - Social and Behavioral

Sciences, 78, 150-154.

https://doi.org/10.1016/j.sbspro.2013.04. 269

Sudarmanto, S., Pamungkas, J., \& Putranti, F. C. (2012). Peningkatan kemampuan motorik kasar melalui tari Aswa Tamtama pada Kelompok B Di TK ABA Wirobrajan I. Jurnal Pendidikan Anak, 1(2). Retrieved from https://journal.uny.ac.id/index.php/jpa/ar ticle/view/3020

Suharyo, I. (2009). The catholic way. Yogakarta: Percetakan Kanisius.

Suwarjo, S., Maryatun, I. B., \& Kusumadewi, N. (2012). Penerapan student centered approach pada pembelajaran taman kanak-kanak kelompok B (studi kasus di sekolah laboratorium rumah citta). Jurnal Pendidikan Anak, 1(1). Retrieved from

https://journal.uny.ac.id/index.php/jpa/ar ticle/view/2924

Suyanto, S. (2003). Konsep dasar pendidikan anak usia dini. Yogyakarta: Universitas Negeri Yogyakarta.

Tilaar, H. A. R., \& Nugroho, R. (2008). Kebijakan pendidikan: pengantar untuk memahami kebijakan pendidikan dan kebijakan pendidikan sebagai kebijakan publik. Yogyakarta: Pustaka Pelajar.

Wibowo, U. B. (2016). Kepemimpinan (untuk) pembelajaran: jembatan untuk memperkuat pembentukan karakter. Jurnal Pembangunan Pendidikan: Fondasi Dan Aplikasi, 4(2), 194. https://doi.org/10.21831/jppfa.v4i2.1242 5

Zamroni. (2007). Meningkatkan mutu sekolah, teori, strategi dan prosedur. Jakarta: PSAP Muhammadiyah. 